\title{
A CULPA UNIVERSAL COMO CONSENSO ÉTICO ENTRE A FILOSOFIA, O CRISTIANisMo, o Budismo E BRAMANisMo, SEgundo SCHOPENHAUER
}

\author{
[UNIVERSAL GUILT AS ETHICAL AGREEMENT BETWEEN PHILOSOPHY, CHRISTIANITY, BUDDHISM AND \\ BRAHMANISM]
}

\author{
Eli Wagner Rodrigues * \\ Universidade Etadual de São Paulo-UNESP, Brasil
}

\begin{abstract}
Resumo: Schopenhauer afirma uma identidade entre o cristianismo o budismo e o bramanismo em relação à noção de culpabilidade humana e do mundo. Segundo o filósofo, as três religiões afirmam uma culpa que é carregada pelo ser humano devido à sua própria existência. Considerando o problema das fontes às quais Schopenhauer recorreu em seus estudos sobre as religiões orientais, sobretudo em relação aos Upanishades, questiona-se neste artigo se a posição de aproximação e identidade imputativa em relação ao ser humano e ao mundo, afirmada por ele é, de fato, sustentável a partir dos argumentos apresentados nos dois volumes do Mundo como vontade e representação e nos Parerga e Paralipomena.

Palavras-chave: culpa; cristianismo; budismo; bramanismo
\end{abstract}

ABSTRACT: Schopenhauer affirms an identity between Christianity, Buddhism and Brahminism in relation to the notion of human and world guilt. According to the philosopher, the three religions affirm a guilt that is carried by the human being due to his own existence. Considering the problem of the sources to which Schopenhauer resorted in his studies on Eastern religions, especially in relation to the Upanishads, it is questioned in this article whether the position of approximation and imputative identity in relation to the human being and the world, affirmed by him, in fact, sustainable based on the arguments presented in the two volumes of the World as will and representation and in Parerga and Paralipomena.

KeYwords: Guilt; Christianity; Buddhism; Brahmanism

\section{INTRODUÇÃo}

A questão central sobre a diferença entre as religiões, segundo Schopenhauer, A diz respeito ao problema da culpa (Schuld $)^{1}$. A avaliação do filósofo em relação às doutrinas religiosas segue um critério de negação (condenação) e afirmação do mundo e da vida sempre em perspectiva de um necessário ordenamento moral. Segundo Schopenhauer, a forma como as religiões apresentam uma interpretação ética sobre o mundo determina sua relação com a verdade e, portanto, seu valor enquanto conteúdo alegórico.

Se uma religião expõe a existência humana e a existência do próprio mundo como justificada por si mesma em sua inocência e as louvam, ou celebram, ela está distante da verdade, não captou o verdadeiro sentido do mundo em sua doutrina. Se,

* Doutor em Filosofia. Professor do Departamento de Ciências Humanas da Faculdade de Arquitetura, Artes e Comunicação - Faac - da Universidade Estadual Paulista Julio de Mesquita Filho-UNESP.e-mail: elivagner@faac.unesp.br 
pelo contrário, uma religião considera a existência, o mundo e o homem como imputáveis, isto é, como portadores de uma culpa original, nas palavras de Schopenhauer, como "algo que só pode ser concebido como a consequência da nossa culpa e, por conseguinte, na verdade não deveria ser...'( Schopenhuaer, 2015, p. 207), ela está próxima da verdade e, por essa razão, tem valor como conhecimento metafísico

80 do mundo, tendo captado a verdade ética por detrás dos fenômenos e das ações humanas.

Eu não posso, como geralmente é feito, estabelecer a DIFERENÇA FUNDAMENTAL entre todas as religiões pelo fato de serem ou monoteístas, politeístas, panteístas ou ateístas; mas apenas pelo fato de serem otimistas ou pessimistas, isto é, se expõem a existência deste mundo como justificada por si mesma, portanto, a louvam e celebram, ou a consideram como algo que só pode ser concebido como a sequência da nossa culpa e, por conseguinte, em verdade não deveria ser, na medida em que reconhecem que dor e morte não podem jazer na ordem eterna, originária e imutável das coisas, não podem jazer naquilo que deve ser em todos os sentidos.(Schopenhuaer, 2015, p. 207)

Otimismo e pessimismo dizem respeito diretamente à inocência (unschuld) e à culpa (Schuld). A posição otimista aposta, por assim dizer, em uma inocência ou em uma redenção, a perspectiva pessimista aponta a culpa como um elemento indissociável em relação à existência humana. Além desse critério de valoração e julgamento (condenação) em relação às religiões, e baseado nele mesmo, Schopenhauer afirma que existe identidade entre brahmanismo, budismo e cristianismo no que diz respeito ao juízo de imputação do homem e do mundo. Segundo o filósofo, as três religiões afirmam uma "culpa que é carregada pelo ser humano devido à própria existência dele"( Schopenhuaer, 2015, 720)

\section{Schuld, UnSChUld, SCChuldlos E Schuldung - CulPa, INOCÊNCIA, INOCENTE, CULPADO}

A questão remete ao núcleo ético fundamental da filosofia de Schopenhauer e aponta para a visão que o filósofo desenvolve sobre as ideias de justiça e sofrimento, chaves para a compreensão do mundo como vontade em perspectiva ética. Segundo Schopenhauer, o que esteve como pano de fundo das questões éticas desde a filosofia antiga até a sua época teria sido a questão do sofrimento do inocente ou do virtuoso (schuldlos, tugendhaft). A questão que movia os estóicos e os peripatéticos e acadêmicos era a demonstração da relação de necessidade entre virtude e felicidade. Aquele que fosse inocente e virtuoso, segundo essas doutrinas, deveria ter uma vida feliz. Como a realidade sempre gritou contra essa teoria uma das questões fundamentais da filosofia moral seria explicar a relação entre justiça e sofrimento. Ora, sabemos que para Schopenhauer a solução está na doutrina cristã segundo a qual "as obras não justificam". O ser humano não pode estar em estado de "culpa omni carens" (livre de toda a culpa). Antes, sua condição existencial é a de um ser culpado (schuldig) por nascimento.

A culpabilidade inata, no entanto, traz outros problemas tanto para os criacionistas quanto para aqueles que concebem a existência a partir do nada ou de uma instância inescrutável. Para os criacionistas surge a difícil questão do julgamento da essência ou da própria natureza humana. Esta questão estabelece que, se o homem é criatura, isto é, se foi criado a partir de outro ser, a responsabilidade sobre sua natureza deveria ser atribuída ao seu criador e, portanto, a culpa (inata) não poderia ser atribuída ao próprio homem. O criador seria o responsável pela essência pecaminosa, culpada e maligna do homem. Esse raciocínio, no entanto, coloca em questão uma contradição 
com os atributos divinos de perfeição e bondade.

Percebe-se que esse viés investigativo nos encaminha rapidamente para o problema teológico do surgimento do mal e ele está diretamente ligado, tanto na obra de Schopenhauer quanto na própria tradição do pensamento teológico ocidental, às questões desenvolvidas por Santo Agostinho e por Lutero entre outros tantos que se debruçaram sobre a relação entre os conceitos de justiça, relativas a questão do sofrimento e da essência humana. Schopenhauer vai se ocupar com esse problema em seu capítulo sobre a justiça eterna ( $\$ 63$ do primeiro volume do "Mundo como vontade e representação").

No caso da teologia cristã, o problema do mal está diretamente relacionado com a natureza pecaminosa do homem. Santo Agostinho teria sido aquele que, através da elaboração da doutirna do livre-arbítrio, adotada pela tradição cristã posterior, teria resolvido o problema do mal como um não-ser. Para Santo Agostinho, todas as coisas que existem são boas e o mal não é uma substância, mas é ausência do bem, ele não possui um status ontológico. O mal só pode ser identificado com o pecado e o pecado é unicamente obra do homem, o ser falível, ao contrário do ser infalível que é Deus. Para que essa doutrina ficasse completa em sua estrutura lógico-teológica era preciso que o homem fosse dotado de uma instância de decisão que fosse responsável pela opção pelo mal, assim teria nascido e se perpetuado a ideia de um livre arbítrio absoluto. Para Schopehauer, no entanto, toda a complexidade que envolve a doutrina do liberum arbitrum indiferentiae está ligada à tentativa dos teólogos, sobretudo de Santo Agostinho, de inocentar a divindade da acusação de, ao criar o homem, ter criado o mal. A doutrina do pecado original traria como efeito colateral não somente a necessidade, mas a intenção de atribuição da culpa a um ente que possa, por seus atributos, ser considerado culpado sem que a arquitetônica teológico-teodicéia desmoronasse. Esta necessidade de coerência interna da teologia apela para a necessidade de imputação de um ser que tenha em si um princípio de falibilidade e de erro, esse ente não poderia ser o criador todo-poderoso. O problema da culpa, então, está ligado ao problema do mal e, portanto, é eminentemente um problema do teísmo criacionista. Concepções teológicas distintas do modelo teológico monoteísta judaico manifestarão diferentes concepções de culpabilidade e princípios distintos para atribuição de malignidade ao mundo e ao homem.

A solução para o problema do sofrimento, ou mais exatamente sobre o sentido do sofrimento, é encaminhado, na teologia cristã, a partir da ideia de pecado. A culpa pelo erro e pela morte recaem sobre o homem. Ele próprio, por natureza, é culpado (schuldig) por sua dor e sofrimento, que tem origem em suas ações. Deus, na perscpectiva do cristianismo é isento de culpa (schuldfrei), para isso trabalharam os intelectuais da tradição teológica, não somente Santo Agostinho, mas também Boécio, Santo Anselmo e São Tomás de Aquino. Estes autores submeteram toda a investigação sobre o sofrimento humano e sobre a imputação à estrutura lógica da teologia. Segundo essa tradição, para o homem não pode haver presunção de inocência (unschuldsvermutung), para Deus não pode haver presunção de culpa (Vermutung der Schuld).

A afirmação de semelhança entre as visões éticas das religiões em questão, proposta por Schopenhauer, representaria, de fato, a ideia segundo a qual seriam esses mesmos fundamentos que estruturam as perspectivas teológicas do Bramanismo e do Budismo? Ou Schopenhauer está apenas indicando uma concepção geral de fundo, uma aproximação da noção de culpabilidade entre as tradições religiosas do oriente e do ocidente. $\mathrm{O}$ que veremos é que, nas duas tradições religiosas orientais citadas, não se concebe um ordenamento moral do mundo a partir da figura de um legislador supremo como princípio único, legislador universal, infalível e isento de culpa. A ideia de imputação ou de culpa nas religões orientais não tem origem em uma instância de julgamento concebida como um deus inquisidor como no Judaísmo e no cristianismo. 
Schopenhauer tinha consciência dessa diferença, mas insiste na ideia de aproximação e comparação. Esta insistência pode nos conduzir a duas posturas críticas: ou a ideia de aproximação é apenas uma sugestão e a externalização de um insigth relacionado à uma concepção ética generalista de avaliação da vida como uma experiência de sofrimento por essência, como uma tentativa de obter confirmação de princípios de sua filosofia a

82 fim de demarcar sua originalidade e relevância de seu sistema filosófico, ou é o resultado de equívocos e falta de aprofundamento dos temas na literatura sagrada do oriente, originados pela precariedade das fontes as quais ele teve acesso.

A julgar pela fortuna crítica relativa ao problema das fontes, ambas as teses podem estar corretas, e elas não são excludentes.

\section{CULPA E DIENTIDADE ENTRE O CRISTINAISMO, BUDISMO E BRAMANISMO}

A questão mais problemática, a meu ver, que surge nesse contexto de avaliação dos conteúdos éticos das religiões em questão, está relacionada com a possibilidade de atribuir tanto ao budismo quanto ao hinduísmo a mesma interpretação que o filósofo atribui ao cristianismo, a saber, que estas religiões se constituem como religiões que sustentam a mesma forma de imputação como juízo ético em relação ao mundo e ao ser humano, isto é, se estas religiões atribuem à natureza humana uma falta ou um pecado anterior à própria ação humana, o que significa, em última instância, estabelecer uma definição de "natureza humana". Schopenhauer, nessa questão, adota um princípio da tradição teológica medieval, o esse determina o operari, isto é, a essência determina a ação, o modo de agir. Assim, para o filósofo, como no cristianismo, é a natureza humana que determina sua própria imputação.

Não os indivíduos considerados segundo o princípio de razão, mas a Ideia de humanidade considerada em sua unidade, é o que a doutrina cristã simboliza como a NATUREZA, a AFIRMAÇÃO DA VONTADE DE VIDA, EM ADÃO.(Schopenhauer 2013, p. 469)

A ideia de natureza humana é determinante para o juízo ético negativo que vai se estabelecer sobre o homem e sobre o mundo. No que diz respeito à postulada identidade entre as religiões citadas, nesse aspecto, resta-nos saber se, de fato, no bramanismo e no budismo a mesma concepção de pecado inato se aplica e se a mesma concepção de natureza humana vigora. Antes, porém, acredito, é preciso esclarecer o que exatatamente Schopenhauer entende por "identidade do núcleo mais íntimo" das religiões em questão. Na tradução do professor do Jair Barbosa para o português do segundo volume do Mundo encontramos o que segue.

O núcleo mais íntimo e o espírito do cristianismo é idêntico com aquele do brahmanismo e buddhismo: todos ensinam uma culpa que é carregada pelo gênero humano devido à própria existência dele: só que o cristianismo não procede aqui, com aquelas mais antigas doutrinas de fé, direta e abertamente, logo, não estabelece a culpa como inerente à existência mesma, mas a faz originar-se através de um ato do primeiro par de humanos. Isso, no entanto, só foi possível mediante a ficção de um liberum arbitrium indifferentiaie, e era necessária somente por causa do dogma judeu fundamental, no qual esta doutrina devia implantar-se.( Schopenhuaer, 2015, p. 720)

Para evitar uma afirmação questionável e imprecisa, segundo a qual as citadas religiões são idênticas, Schopenhauer usa as expressões "o núcleo mais íntimo" (innerste Kern) também usa o termo "espírito" (Geist), isto é, a ideia central, ou original, o fundamento, como recurso textual para atenuar sua afirmação. Neste ponto vale retornar ao original para podermos examinar o texto com mais atenção. Der 
Innerste Kern und Geist des Christenthums ist mit dem des Brahmanismus und Buddhaismus der selbe (o mesmo). Schopenhauer, 1988, §48 p. 702).

Schopenhauer está querendo apontar, a meu ver, apenas a identidade da concepção imputativa, isto é, a afirmação de uma culpa existencial e inerente ao ser humano. A forma como essa culpa é adquirida e deve ser expiada, no entanto, determinará inúmeras diferenças em relação às doutrinas, preceitos e práticas religiosas. Além disso, o filósofo afirma que nas religiões denominadas no texto como "mais antigas doutrinas", (bramanismo e budismo), a imputação não é inerente à "existência mesma".

Schopenhauer é cauteloso em relação a sua afirmação e demonstra ser consciente de que, nas diferentes tradições religiosas, os problemas que envolvem as consequências e desdobramentos doutrinários dessa atribuição de culpa ao mundo e ao homem foram tratados ou solucionados de maneira distinta. Por este motivo, em algumas passagens de sua obra, acentua diferenças entre a tradição religiosa que se desenvolveu na Europa e a forma como o oriente concebe a existência e a ética.

Nós, por outro lado, agora enviamos clergymen ingleses e tecelões morávios de confraria aos brãhmanas, a fim de por compaixão melhor doutrinar a estes, fazendo-lhes entender que são feitos de nada e devem agradecer e alegrar-se com isso. Mas ocorre ex atamente como se disparássemos um tiro contra um rochedo. Nunca as nossas religiões deitaram ou irão deitar raízes na Índia: a sabedoria ancestral da raça humana não será reprimida pelos acontecimentos na Galileia. Por outro lado, a sabedoria indiana avança sobre a Europa e produzirá uma mudança fundamental em nosso saber e pensamento.( Schopenhauer 2013, p. 414)

O que não se pode perder de vista na interpretação do texto de Schopenhauer, a meu ver, é a forma como o filósofo apresenta a sua concepção de identidade entre as tradições religiosas em questão. As expressões "núcleo mais íntimo" e "espírito" na frase "O núcleo mais íntimo e o espírito do cristianismo é idêntico com aquele do brahmanismo e do buddhismo..." ${ }^{2}$, guardam, por mais que pareçam precisos e pontuais, um problema crucial, sobretudo para as áreas da teologia e religião comparada. $\mathrm{O}$ núcleo mais íntimo e o espírito do Brahmanismo e do Buddhismo seriam então, de fato, inculpatórios da natureza humana e do mundo da mesma forma que o cristianismo? Esse ponto mereçe um esclarecimento mais amplo.

\section{O PECADO ORIGINAL}

O fundamento da imputação humana no cristianismo está baseado no dogma do pecado original, sustentado por Schopenhauer como a "única verdade metafísica do velho testamento" (SCHOPENHAUER, 2015, § 46, p. 692). A validade da tese de Schopenhauer sobre a identidade impculpatória das religiões orientais com 0 cristianismo dependeria da constatação de uma dogmática próxima da concepção de pecado original, que tem como pressuposto uma queda, uma degeneração do ser humano em relação à uma condição anterior, no Budismo e no Bramanismo. Nesse sentido, e no mesmo espírito interpretativo sugerido por Schopenhauer, empreende-se aqui, mesmo que de maneira introdutória, uma tentativa de estabelecer um paralelo conceitual entre o dogma do pecado original e aspectos das doutrinas budistas e bramanistas. Se esse paralelo se revelar equívoco, a tese de Schopenhauer perde sustentação. A suspeita sobre a citada tese de identidade e paralelismo ocidente-oriente se baseia principalmente na atualização da pesquisa sobre as fontes através das quais Schopenhauer estabeleceu e fundamentou suas interpretaçãoes relativas às religiões orientais, sobretudo nos trabalhos de Urs App, Deckock e. Sobre o conceito de 
aseidade destacam-se os trabalhos de Young, e Debona,

Ora, para Schopenhauer a questão sobre o pecado original se decide, de fato, no nascimento, pois o próprio nascimento do ser humano é o ato da vontade livre. "Essa culpabilidade que o ser humano traz ao mundo desde o nascimento não pode parecer absurda senão para quem o considera como tendo acabado de vir do nada e como a obra 84 de um outro." (SCHOPENHAUER , 2015 § 48, p. 719). Assim, mesmo que o ser humano pratique boas ações, a essência e a existência humanas já determinam uma culpa e uma condenação. É por essa razão que Schopenhauer defende a interpretação de Lutero sobre a salvação pela graça. Se a natureza humana é determinada pelo pecado, se o esse determina o operari, as obras, as ações humanas, não podem ser um caminho de justificação e salvação. No debate acerca da relação entre virtude, justiça e felicidade, Schopenhauer não se alinha com estóicos e peripatéticos, tampouco com qualquer doutrina que associe felicidade com virtude como uma relação necessária e de consequência. Para o filósofo, o que é bom e o que é honesto não está isento de culpa. A razão da imputação está na sua vontade, essa sim determina sua natureza e o aprisiona a sofrimentos físicos e espirituais. Esse é o sentido de sermos definidos como pecadores na teologia cristã e esta seria a razão da necessidade de uma redenção.

Neste ponto Schopenhauer admite uma diferença entre as religiões ditas pessimistas e aponta para uma artimanha da teologia cristã. Esta acusação, a meu ver, confere originalidade e contundência ao ataque que ele faz ao segredo da inculpação do indivíduo e a transferência de culpa do criador para a criatura, o que seria visto como um absurdo. Segundo o filósofo, enquanto o brahmanismo e o budismo estabelecem uma culpa como inerente à existência mesma e o fazem diretamente (direkt) e abertamente (unumwunden), o cristianismo a faz originar-se de um primeiro ato dos primeiros humanos. Ora, este primeiro ato inaugura junto com a condenação do homem, a grande artimanha de inversão de culpa do criador para a criatura. O liberum arbitrium indiferentiae teria sido estrategicamente implantado na lógica da imputação para reestabelecer a lógica de uma justiça segundo a qual a divindade deveria permanecer com seus atributos de perfeição, benignidade e onipotência.

Este efeito da teoria do livre arbítrio, acusa Schopenhauer, resolveria alguns problemas críticos da teologia cristã. Tal operação escusa, que se traveste de bondade, pois supostamente atribui ao homem um benefício, a liberdade, apenas o condena e justifica um perfeito plano de inculpação do ser criado em relação ao criador. Schopenhauer completa sua denúncia apontando a verdadeira causa desse malabarismo lógico-teológico, a adequação do cristianismo ao dogma do judaísmo, segundo o qual a Lei deve se impor ao homem no sentido de mudar seus atos. O sentido bíblico de nomos (lei), segundo Schopenhauer, se impõe a um ser que deve adequar seus atos sem a possibilidade de mudança de sua essência.

A dificuldade que encontramos aqui diz respeito aos conceitos de essência e existência. Para Schopenhauer o homem possui uma essência volitiva e esta determina seu ser e seu agir (operari sequitur esse). Sua posição em relação a este problema vai apontar para a natureza da vontade e não para uma ideia de criação. Nesse sentido, criticando a contradição da teoria teológico-criacionista ele aponta que não seria possível e não seria justo julgar um ser criado sem implicar aquele que o criou no julgamento, pois aquele que que cria um ser existente, necessariamente determina a essência do ser criado.

No raciocínio de Schopenhauer, se o homem tende para uma malignidade ou se é, de fato, um ser mau, no sentido de seu egoísmo de seus apegos sensoriais, aos prazeres, e mesmo à maldade em si, essa ideia de natureza só faria sentido se a concebermos como uma essência e uma essência é algo que não se adquiri, antes é inata. Como Schopenhauer não está sustentando uma teoria da criação, mas está apenas interpretando filosoficamente a doutrina cristã, ele afirma que com a essentia e a existentia do ser humano já entraria em cena a sua culpa. Como sua essência é vontade, 
antes mesmo de agir, sua culpa já é efetiva. Ora, esta culpa, então, em termos de uma passagem do essencial para o existencial reside na afirmação da vontade, traduzida pelos atos do corpo. Nessa afirmação da vontade, inerente ao ser humano, está o inatismo da culpa e a origem da dívida que o homem contrai com a natureza.

\section{A IMPUTAÇ̃̃o NAS RELIGIÕES ORIENTAIS}

A ideia central da concepção imputativa do homem contida na filosofia de Schopenhauer está, de fato, bastante próxima da concepção moral do cristianismo. $\mathrm{O}$ que trago à discussão porém, como já anunciei, seria a coerência da tese que aponta a identidade entre a concepção imputativa do cristianismo em relação às doutrinas religiosas orientais. Seria exatamente da mesma forma que o brahmanismo e o budismo concebem a culpa humana? E seria o caminho de salvação de fato idêntico àquele apontado por Schopenhauer em sua filosofia e em sua interpretação do cristianismo?

O uso do termo "idêntico" nesse contexto não é adequado. Schopenhauer utiliza o termo "o mesmo" (der selbe) que é menos enfático que "identisch", que deriva de "Identität". "Der Innerste Kern und Geist des Christenthums ist mit dem des Brahmanismus und Buddhaismus der selbe" (Schopenhauer, WWV, K. 48). Se considerarmos essa afirmação do capítulo 48 do segundo volume do Mundo, segundo a qual considera-se o espírito, e não a letra, isto é, não a interpretação exata das doutrinas como portadoras da idêntica visão sobre a culpa existencial, mas uma aproximação de sentido e mesma concepção geral, a argumentação de Schopenhauer, a meu ver, é bastante plausível. Afirmar, porém, que o espírito dessas doutrinas é idêntico soa temeroso. Vale ressaltar que nesses exercícios de interpretação, o filósofo antecipa o que veio a ser denominado por religião comparada, disciplina que exige uma apurada noção de flexibilidade interpretativa e, muitas vezes, dá mais ênfase ao trabalho de aproximação do que propriamente ao rigor historiográfico e exegético dos textos sagrados e das doutrinas.

A complexa estrutura ético-teológica da qual nos apropriamos aqui pode ser dividida em dois aspectos fundamentais: a estrutura de imputação do ser humano, caracterizado no cristianismo como um ser essencialmente culpado, e as concepções de redenção desse estado de culpabilidade, em outras palavras na ideia de uma queda e na concepção de um caminho de salvação. Nessa concepção a ideia de eu e de indivíduo é fundamental para a imputação. Aquele que é culpado é um indivíduo, determinado por um núcleo volitivo que o leva ao pecado, mas que é dotado de liberdade para negar a ação que o condena.

Não há lugar, no cristianismo, para uma difusão da individuação, para uma relativização do eu ou para uma suspensão ou diluição da indivualidade. Existe, obviamente a espécie humana em um quadro teleológico de queda e redenção, caracterizado pela Felix $\mathrm{Culpa}^{3}$, mas a culpabilidade é, diferentemente, por exemplo, de certa tradição grega arcaica que concebia a culpa como hereditária em relação aos pais e antecessores. A culpabilidade é individual e está baseada na ideia de um eu, de uma individuação, de um núcleo autônomo de imculpação. Em linhas gerais, o que se afirma como um eu é essencialmente contrário ao que pretende enunciar maioria das tradições das religiões orientais.

A noção de Atman, como um pronome reflexivo, um si-mesmo, uma subjetividade, na tradição dos Unpanishads é idêntico ao princípio uno e fundamental da totalidade das coisas (Brahman). Em outras palavras o fundamento último de todas as coisas não é distinto do fundamento da subjetividade. A palavra para esta subjetividade nos Upanishads é Atman. Ora, não é possível uma imputação de Atman na forma como se concebe a imputação relacionada com a alma no contexto da teologia cristã. A teologia cristã opera com a ideia de um indivíduo atômico, personificado em 
um eu responsável por seus atos, que recebe uma condenação pela forma como age. Se essa concepção foi direta e tão somente influenciada pela tradição filosófica ocidental, que apresenta um desenvolvimento baseado na noção de individualidade, de fato, atomística, isto é, de um eu particular detentor de uma racionalidade e de uma liberdade de agir que é desenvolvido pelos conceitos de alma, consciência, substância e sujeito cognitivo, isso pode ser questionado. A concepção de unicidade nuclear pontual do indivíduo, do eu, perdura, na tradição filosófica ocidental, pelo menos até Hume, que apresentará uma concepção de eu baseada na ideia de um teatro de percepções. Para esta tradição a noção de culpabilidade individual se desenvolve de maneira a não conceber uma extrapolação da culpa para além dos limites desse eu como núcleo, como pessoa individual, como uma subjetividade responsável pelos atos. Esta, aliás, é a grande diferença que podemos apontar a partir de uma comparação entre as tradições religiosas ocidental e oriental.

Talvez a maior diferença entre as duas tradições tenha sido uma ênfase, na tradição oriental em relação à descontrução de uma noção de eu, a ênfase na necessidade de um esvaziamento do eu, ao passo que na tradição ocidental essa preocupação não aparece com grande ênfase e, pelo contrário, o que fundamenta a própria estrutura da teologia da redenção é a necessária conceção de um eu nuclear, pontual, único e responsável, isto é imputável. A ideia da conservação de um eu como núcleo das percepções, da cognição e das decisões, a própria individuação, não é um empecílio à salvação para a tradição religiosa ocidental e é nesse sentido que a concepção de redenção é diferente da concepção vigente nas religiões orientais.

A redenção se dá por intermédio de uma transcendência que não exige a dissolução do eu, da dissolução do individual, dessa maneira o culpado, aquele que deve ser salvo, é um indivíduo distinto em essência, do ser que opera a salvação. Em suma, na tradição ocidental do pensamento o eu, a individuação, não são impecilhos à dimensão soteriológica ao passo que para a tradição oriental é fundamental, para a soterilogia, a eliminação do que está apegado ao eu para a eliminação do sofrimento. Para o ocidente a transformação do eu ocorre pela graça e Schopenhuaer não foi deixou de notar a importância desse aspecto da soteriologia cristã.

Ora, a diferença radical que deve ser destacada entre as duas tradições reside na concepção segundo a qual, esse eu, que é fundamento essencial a toda a estrutura de conhecimento e imputação para a tradição do ocidente (filosofia e religião) é justamente, para a tradição religiosa oriental, o princípio do erro cognitivo que leva ao sofrimento.

Essa distinção, impõe um ponto de vista que, de alguma forma, entra em contradição com a afirmação de Schopenhauer segundoa qual o espírito e o núcleo mais íntimo da doutrina cristã da imputação do homem é a mesma das religiões orientais (Bramanismo e Budismo).

Se no Bramanismo temos a concepção de Atman (Upanishads) que unifica o fundamento último das coisas com a subjetividade, no budismo encontramos a noção de Anatta que, como um dos conceitos básicos da doutrina budista indica uma noçã de "não eu". Este princípio diz respeito à ideia da inexistência de um "eu" permanente e imutável. A concepção de Anatta aponta para a ideia de insubstancialidade de todos os fenômenos do universo. A concepção segundo a qual o universo está em um estado de fluxo interconectado, que tem sua base no conceito de originação interdependente, concepção comum a todas as esolas do budismo, resiste a concepção de uma essência pessoal imutável e independente na forma de um eu.

Vale notar ainda que, no que diz respeito a origem do sofrimento (ignorância) a concepção de um eu pessoal, individual e nuclear na forma de uma essência da subjetividade, aparece como a principal responsável. É a partir da fixação na ideia de um núcleo cognitivo pessoal e essencial que se desenvolvem todos os sentimentos e ações relativas a todas as formas de apego, portanto, para o budismo, todo o trabalho de 
desconstrução da ignorância causadora do sofrimento diz respeito à descontrução da ideia de um eu essencial.

Apontadas essas contradições podemos nos perguntar, então, se Schopenhauer não era consciente dessas diferenças essenciais. Veremos que sim, o filósofo demonstra conhecer claramente a doutrina que considera o eu pessoal, a individuação, como uma ilusão. É esta concepção, aliás, em essência, que fundamenta toda sua reflexão sobre os conceitos de Véu de Maia e de principium individuationis, um dos pilares epistemológicos de seu sistema filosófico, como vemos no parágrafo 63 do primeiro volume do Mundo e em inúmeras passagens de sua obra "..envolto como está no princípio individuationis, enganado pelo Véu de Maia...assim também o homem individual está sentado tranqüilo.. no qual o indivíduo conhece as coisas como fenômeno."(Schopenhauer 2013, p. 450)

Schopenhauer adota uma concepção de eu e de individuação como ilusória em sua teoria do conhecimento e se, de fato, não adota a mesma concepção em relação a questão da culpabilidade humana, uma vez que endossa o dogma do pecado orginal, cujo núcleo conceitual está fundado no princípio de indivíduo essencial, de um eu nuclear positivo, isso só pode ser compreendido, a meu ver, pela forma como o filósofo aborda a ideia de culpabilidade e da forma como ele interpreta as culturas religiosas, a saber, de maneira alegórica (sensu alegorico).

A culpabilidade, a imputação, a que o filósofo se refere em inúmeras passagens de sua obra diz respeito à constatação da afirmação da vontade que não pode ser atribuída a outro ser que não o próprio ser humano que afirma a vida.

Minha filosofia, no entanto, é a única que concede à moral seus plenos e completos direitos: pois, tão somente se a essência íntima do ser humano é sua própria VONTADE, por conseguinte, apenas se ele, no sentido mais estrito do termo, é sua própria obra, são seus atos exclusivamente seus e assim são-lhes imputáveis. Por outro lado, se o ser humano tem uma origem outra ou é obra de um ser diferente de si mesmo, toda a sua culpa recai sobre essa origem ou autor. Pois operari sequitur esse. (Schopenhauer 2015, p. 704)

Quando Schopenhauer aponta o pecado original como uma verdade alegórica ele está se referindo a forma como a tradição religiosa deu consistência discursiva para a afirmação da vontade no indivíduo. Esse aspecto de sua filosofia diz respeito não necessariamente à doutrina de salvação que será esboçada nos últimos parágrafos do livro quarto do primeiro volume do Mundo, mas à constatação de que sua filosofia está em conformidade as tradições religiosas sobre um tema fundamental: o sentido do sofrimento humano.

Brahma cria o mundo por meio de uma espécie de pecado original, ou engano, permanece nele, porém, para expiá-lo, até que dele se redima. Muito bem! No Budismo, ele surge em consequência de um turvamento inexplicável, após um longo período de paz, na claridade celeste do bem-aventurado estado de nirvana, alcançado por meio da penitência, portanto, surge através de uma espécie de fatalidade que contudo deve ser entendida moralmente, embora possua uma imagem física correspondente e análoga, pelo surgimento inexplicável de uma nebulosa originária que se transforma em um sol. Por isso ele se torna gradualmente, por consequência de falhas morais, fisicamente pior e sempre piorando até assumir o aspecto triste que tem no presente. (Schopenhauer 2012, p. 158)

A analogia com o dogma cristão do pecado original está ligada ao equilíbrio da balança da justiça eterna e em seus pratos estão colocados o sofrimento de um lado e a culpa de outro. "Nesse sentido podemos dizer: o mundo mesmo é o tribunal do mundo. Pudesse alguém colocar toda a penúria do mundo em UM prato da balança, e toda a 
culpa no outro, o fiel permaneceria no meio.” (Schopenhauer 2013, p. 408)

Ao final a solução que Schopenhauer apresenta para o problema do sofrimento é metafísica e dogmática, apesar de ser contundente no aspecto que diz respeito à aproximação com as tradições religiosas, e mesmo por este motivo, pois ele postula uma concepção de justiça cósmica e eterna a fim de equilibrar (explicar) o sentido do sofrimento humano.

\section{O VERDADEIRO PROBLEMA DA FILOSOFIA: A CONTINGÊNCIA DO SOFRIMENTO}

A contingência do sofrimento é eleita como o maior dos problemas da filosofia. O que o filósofo não pode aceitar é que, em suas palavras, "a dor infinita, que se origina da miséria essencial à vida e da qual o mundo está repleto, seja sem proppósito e puramente contingente". (Schopenhauer 2012, p. 147)

Para evitar a contingência do sofrimento, isto é, sua falta de sentido, o filósofo prefere adotar uma explicação metafísica, dogmática, a culpabilidade que é figurada por um dogma religioso, sob alegação de que o dogma representa, em última instância, uma verdade inalcançável ao discurso racional, uma verdade sensu alegórico. O significado de culpa, portanto, para o filósofo está relacionado com o equilíbrio que o sofrimento contingente exige da linguagem da filosofia moral. Se não se oferece o contra-peso da culpa para a realidade do sofrimento humano rompe-se com a ideia de ordenamento moral do mundo e o sentido ético da existência se desfaz, dissolve-se em uma realidade absurda na qual os atos, ações, movimentos da natureza e toda a efetividade só possuem um sentido físico, contingente.

Se a finalidade mais imediata e próxima de nossa vida não é o sofrimento, então nossa existência é o maior contrasenso do mundo. Pois é absurdo supor que a dor inifinita, que se origina da miséria essencial à vida e da qual o mundo está repleto, seja sem propósito e puramente contingente.(Schopenhauer 2013, p. 147)

A contingência do sofrimento é o problema central da filosofia de Schopenhauer. Conseguir explicar o sentido, o própósito, dessa "dor infinita que se origina da miséria essencial à vida" corresponde a solucionar o enigma do mundo. No segundo volume do Mundo Schopenhauer deixa claro qual é o problema central da filosofia, a saber, conseguir resolver o problema da contingência do sofrimento sem aceitar as soluções metafísico-dogmáticas, pueris, do teísmo e do panteísmo.

Fazer a ligação da força que produz o fenômeno do mundo, portanto, que determina a sua índole, com a moralidade da disposição, e com isso demonstrar uma ordem MORAL do mundo como fundamento da ordem física - este foi desde Sócrates o problema da filosofia.( Schopenhauer 2015, p. 704)

Essa ligação só pode ser demonstrada, acredita Schopenhauer, se conectarmos a força que impulsiona o mundo à nossa própria Vontade, a vontade em nós (Willen in uns). Esta façanha filosófica teria sido efetuada, afirma Schopenhauer sem modéstia, somente por ele especialmente nos escritos "Sobre a vontade na Natureza" e nos parágrafos 63 e 64 do primeiro volume do Mundo que tratam da justiça eterna. Com estas indicações, afirma, estariam "efetivamente resolvido pela primeira vez o problema suscitado por Sócrates, e satisfeita a exigência da razão pensante orientada para questões morais". ( Schopenhauer 2015, p. 704)

Logo a seguir, Schopenhauer atenua sua afirmação sugerindo que nem todas as questões da ética são resolvidas pelo pensamento único. "Nunca, todavia, pretendi instituir uma filosofia que não deixasse questão alguma se resposta. Num sentido destes a filosofia é realmente impossível: ela seria deoutrina da onisciência."

$\mathrm{O}$ que se pode concluir é que Schopenhauer se vê, nesse caso, como todas as 
tradições e pensadores que trataram de um tema tão crucial e árduo, talvez mesmo um tema insolúvel, diante de um limite que não é somente um limite de linguagem e da própria filosofia moral, mas um limite de compreensão a partir do ponto de vista humano.

\section{O PROBLEMA DAS FONTES}

Mas, não seria o caso, antes de mais nada, de questionar a apropriação que Schopenhauer faz das religiões citadas, não seria, em primeiro lugar, como questão primordial, questionar a interpretação schopenhaueriana das religiões tradicionais? Consciente de que esta questão já foi amplamente discutida e que algumas interpretações já se tornaram bastante conhecidas, gostaria de destacar aquela que aponta para a ideia segundo a qual Schopenhauer estabelece um vínculo de sua filosofia com a religião sobretudo instrumentalizando a idéia do pecado original e da queda do homem como um paralelo, como fundamento teológico, de sua interpretação do mundo como um "vale de lágrimas", pois a introdução do pecado como um mal originário a partir do proóprio homem institui e justifica a culpa, contrapeso para o sofrimento na balança da justiça eterna e a idéia da redenção encaminhada por dois caminhos, pelo efeito da graça ou pela experiência radical do sofrimento. Para esta última possibilidade a paixão de Cristo figuraria como a alegoria devida. Analisando o texto de Horkheimer "O pensamento de Schopenhauer em relação à ciência e à religião" Flamarion Caldeira assinala escreve:

Aqui Horkheimer parece concordar inteiramente com a tese de Schopenhauer segundo a qual sua filosofia deve ser considerada a autêntica filosofia cristã. Mas qual a interpretação que Schopenhauer tem do cristianismo que o permite julgar que sua filosofia, mesmo ateia e imanente, é a filosofia propriamente cristã? Os dois pontos principais que fazem Schopenhauer aproximar sua filosofia da religião cristã são: a ideia do pecado original, da queda do homem que permite interpretar o mundo como um "vale de lágrimas", e a ideia da redenção do mundo pelo sofrimento, como apresentado na paixão de Cristo (RAMOS, 2008, p. 102)

O que é inegável, a meu ver, é que no caso da aproriação que Schopenhauer faz do cristianismo não se pode negar a pertinência de suas interpretações, apesar da natureza aparentemente contraditória a partir da qual, em geral, o filósofo trata o tema da religião, por vezes a criticando como metafísica do povo e por outras elevando ensinamentos e dogmas ao nível de sua própria filosofia. Inserido na tradição do pensamento filosófico alemão e com trânsito especializado pela teologia cristã a partir, sobretudo, de leituras aprofundadas das obras de Agostinho e Lutero, Schopenhauer consegue extrair e examinar com maestria elementos da teologia cristã que corroboram sua perspectiva imputativa em relação ao ser.

No caso do Bramanísmo e do Budismo, no entanto, religiões às quais o filósofo estende a classificação acima citada como tradições condenatórias do mundo, a meu ver, sua obra não apresenta evidências bibliográficas e argumentos filosóficos suficientes para aprofundar a tese segundo a qual há uma concepção condenatória fundamental do homem e do mundo e que essa imputação ontológica aparece da mesma forma na literatura sagrada oriental. Se há imputação ao devir e se há uma perspectiva de correção e reforma espiritual, de evolução em relação ao estado primitivo de erro e ignorância do homem em relação ao mundo, não se pode afirmar categoricamente que essa imputação é a mesma (der selbe) que ocorre no cristianismo. As tradições orientais, ao apontarem para o problema do erro do homem destacam, por assim dizer, muito mais a perspectiva do efeito maléfico da ignorância na produção do sofrimento do que propriamente uma origem da mal a partir da vontade humana. No caso do 
Bramanismo as fontes de Schopenhauer, como sabemos, foram o Upnek'hat ${ }^{4}$, tradução latina dos Upanishads, a Revista Asiatics Research's, Asiatisches Magazin e Mythologie des Indous.

Além do conhecido problema das fontes, fica claro, na leitura do texto schopenhauriano, que, nos trechos nos quais o filósofo se ocupa dessa aproximação entre cristianismo, Bramanismo e budismo, quando se trata das fontes destas duas úlitmas tradições ele apenas indica sua interpretação e faz uma menção, mas não aprofunda o assunto e não apresenta evidências conclusivas diretamente dos textos sagrados das duas religiões orientais. As razões para essa lacuna exegética são conhecidas pelos estudiosos da relação de Schopenhauer com os textos do oriente. Merece destaque o trabalho de Urs App que, afirma utilizar um método cientificamente mais rigoroso do que a maioria dos pesquisadores adotando como princípio, alerta para os inúmeros equívocos cometidos, em diversos trabalhos e dissertações, em relação aos contatos de Schopenhauer com a tradição oriental. O critério de Urs App, que, a princípio, deveria estar na base de qualquer pesquisa, é simplesmente não imaginar que Schopenhauer tinha domínio sobre os textos sagrados do oriente e essa perspectiva, devemos admitir, abre inúmeras possibilidades interpretativas. Por exemplo, o questionamento da afimação segundo a qual Bramanismo e Budismo são religiões eminetemente pessmistas.

\section{CONSIDERAÇÕES FINAIS}

Parte da atração da filosofia religiosa indiana por Schopenhauer que o levou a traçar paralelos de fato surpreendentes e bastante plausíveis era a característica do idealismo subjetivista das doutrinas orientais. Certa noção de que o mundo fenomenal não teria, de fato, realidade à parte de sua representação. O conceito de véu de Maia, que, grosso modo, representa essa concepção, de que a realidade apreendida pelos sentidos é uma realidade ilusória pertencente antes de tudo à mente do sujeito do conhecimento, não sendo a realidade última das coisas. Ora, Schopenhauer, de fato, sustenta uma forma de idealismo muito próxima dessa concepção que, aliás, já tinha sido desenvolvida, de maneira bastante próxima, a princípio, por Berkeley e, de maneira mais sofisticada, por Kant. Schopenhauer se filia, portanto, com algumas adaptações à esse tradição da filsofia ocidental. Mas, como nota Tarandeep Singh Kang, em sua tese de doutorado apresentada na Cornell University em 2012, além de sua metafísica idealista, para a qual Schopenhauer encontrou análogos europeus contemporâneos, foi o "aparente pessimismo" das religiões orientais que exerceu o maior fascínio sobre Schopenhauer.

Sobre a questão da legitimidade da interpretação schopenhaueriana do bramanismo como uma religião pessimista Dianna Chao Decock, em "O encontro de Schopenhauer com o pensamento indiano: influência e legitimidade.” esclarece:

Schopenhauer é alvo de severas críticas por alguns estudiosos dos textos sagrados indianos, uma vez que ele teve acesso a um material limitado e um tanto quanto questionável. Gestering, por exemplo, acredita que Schopenhauer foi incapaz de compreender a Índia objetivamente, associando a sabedoria indiana ao seu próprio pensamento, enraizado na cultura em que estava inserido. Nesta perspectiva, Schopenhauer seria um etnocêntrico e teria tratado a Índia "como se ela fosse um europeu" sem levar em consideração que a tradição indiana deveria seguir princípios axiológicos inerentes a sua própria cultura. Ale $\mathrm{m}$ de mal interpretar a sabedoria indiana, Gestering critica Schopenhauer por tê-la vinculado ao pensamento pessimista, cuja relação na o se justificaria da mesma forma nos textos sagrados. (Deckok, 2016, p. 30) 
Não obstante as dificuldades em relação às fontes e o risco em relação a tese da aproximação das doutrinas e da afinidade em relação ao modo como se resolve o problema da culpa, de fato, a obra de Schopenhauer apresenta uma interessante aproximação de uma doutrina baseada princípios das filsofias de Platão e de Kant com alguns

As religiões, então, de acordo com essa interpretação, se constituiriam em interpretações da existência baseadas na negação da realidade ao afirmarem que dor e morte são distorções de uma ordem eterna e imutável. Ora, essa concepção de ordem e imutabilidade remonta, além das concepções religiosas citadas, à concepção platônica do ser. Mas, sabemos, é sempre temeroso tratar concepções religiosas tão distintas a partir de pontos de vista generalizantes. A afirmação de identidade entre as religiões, no entanto, não diz respeito, como era de se esperar, a todos os aspectos que envolvem a imputação e a solução que está implicada no resgate dessa culpa primordial. Schopenhauer é cauteloso em relação a sua afirmação e demonstra ser consciente de que, nas diferentes tradições religiosas, os problemas que envolvem as consequências e desdobramentos doutrinários dessa atribuição de culpa ao mundo e ao homem foram tratados ou solucionados de maneira distinta.

O núcleo mais íntimo e o espírito do cristianismo é idêntico com aquele do brahmanismo e do buddhismo: todos ensinam uma culpa que é carregada pelo gênero humano devido à própria existência dele, só que o cristianismo não procede aqui, como aquelas mais antigas doutrinas de fé, direta e abertamente, logo, não estabelece a culpa como inerente à existência mesma, mas a faz originar-se através de um ato do primeiro par de humanos. (Schopenhauer, 2015, p. 720, grifo nosso)

A afirmação é de relevância inegável para a ética pois, se não aponta diretamente para uma ideia de universalidade de um juízo ético pessimista e negativo em relação ao mundo e ao universo humano, aponta para a tese segundo a qual existe uma tendência à atribuição de culpa e responsabilidade ao próprio homem pelo sofrimento de sua espécie. Se a atribuição de culpa ao homem, problema que só se resolve com um esclarecimento sobre o problema da liberdade, a atribuição de culpa ao devir parece-nos uma ideia ainda mais dogmática do que a imputação ao humano.

Mas, a atribuição de uma dívida ao devir não parece ser, ao mesmo tempo, uma atribuição de culpa ao ser humano, nas três religiões elencadas por Schopenhauer, isto é, não decorre, necessariamente de uma imputação do homem, uma imputação do devir. Ao contrário, se se provar uma possibilidade não dogmática de imputação do devir, ficaria mais fácil a imputação da esfera humana. De qualquer forma, a afirmação dessa suposta identidade entre as perspectivas imputativas seja ao homem, seja ao devir, impõe-nos a necessidade de compreender qual o significado da imputação originária, antes de tudo, do próprio devir. A resposta para esta questão, a meu ver, está diretamente relacionada com as noções de sofrimento e justiça, que compõem o núcleo conceitual do problema do ordenamento moral do mundo e dão, por assim dizer e como não poderia deixar de ser, uma conotação subjetivista ao problema. A questão da subjtivação da perspectiva avaliadora da vida comprometeria a própria avaliação. É nesse ponto que a perspectiva negativa recebe uma crítica contundente. Quanto a este problema Nietzsche já nos alertava sobre a contradição que é inerente a um juízo sobre a vida emitido do interior da própria vida. A crítica de Nietzsche aponta para a contradição segundo a qual a vida não poderia ser avaliada por quem a vive. Esta perspectiva crítica pode ser ampliada no sentido de estender a avaliação do julgamento sobre o mundo não somente a um autor ou à um filósofo, mas a toda uma tendência da culltura e sobre toda uma época. Poderíamos citar aqui o panorama cultural levado a efeito pelo romantismo alemão e suas raízes. 


\section{REFERÊNCIAS}

DECKOK, Diana Chao, O encontro de Schopenhauer com o pensamento indiano: influência e legitimidade, Revista Voluntas: Estudos sobre Schopenhauer-Vol. 7, $\mathrm{N}^{\mathrm{o}} 2.2^{\mathrm{o}}$ semestre de 2016. ISSN:2179-3786-pp. 27-37

92 RAMOS, Flamarion Caldeira, Horkheimer leitor de Schopenhauer: uma tradução e um breve comentário, Cadernos de Filosofia Alemã no 12 - jul.-dez. 2008 - p. 99-113.

SING KANG, Tarandeep. The Place of India in Enlightenment and Post-Enlightenment Philosophies of History, Cornell University, 2012.

SCHOPENHAUER, Arthur. Sämtliche Werke. Textkritisch bearbeitet und herausgegeben von Wolfgang Frhr. Löhneysen. Darmstadt: Wissenschaftliche Buchgesellschaft, 1968.

SCHOPENHAUER, Arthur. Werke in fünf Bänden. Nach den Ausgaben letzter Hand. Hrsg. von L. Lütkehaus. Zürich: Haffmans Verlag, 1988 (1988-1989).

SCHOPENHAUER, Arthur. O mundo como vontade e como representação (W I). Trad. Jair Barboza. São Paulo: Editora da Unesp, 2013.

SCHOPENHAUER, Arthur. O mundo como vontade e como representação, Tomo II: Suplementos aos quatro livros do primeiro tomo. Tradução, apresentação, notas e índices de Jair Barboza. $1^{\text {a }}$ ed. São Paulo: Editora Unesp, 2015.

SCHOPENHAUER, Arthur. Sobre a Ética, Tradução de Flamarion C. Ramos, Editora Herda, São Paulo, 2012.

\section{Notas}

$1 \mathrm{O}$ termo Schuld tem uma dupla siginificação em alemão. Traduz-se como culpa e como dívida. Tanto o tradutor das obras de Nietzsche para o portugês Prof. Paulo Cezar Souza quanto o Prof. Jair Barbosa, responsável pela tradução dos dois volumes do Mundo para nosso vernáculo, fazem menção a esta importante ambiguidade em relação ao termo acentuando que ele determina diversas possibilidades interpretativas em relação a natureza da culpa e da forma como se forjou a noção de imputação em relação ao ser humano na cultura ocidental.

2 SCHOPENHAUER, O Mundo como Vontade e como Representação Vol. II, 720. No texto original da edição : Der innerste Kern und Geist des Christenthums ist mit dem des Brahmanismus und Buddhaismus der selbe: sämmtlich lehren sie eine schwere Verschuldung des Mensgeschlechts durch Daseyn selbst; (W II, § 48, p. )

$3 \mathrm{O}$ conceito de felix culpa está ligado à doutrina da queda do homem e a interpreta como um evento que, em última instância, tem um resultado positivo. O que seria, de início um evento infeliz, a queda no pecado original, acaba sendo a possibilidade da redenção pela graça e pelo sacrifício de cristo. Na filosofia da religião o conceito de felix culpa é uma resposta, no contexto das teodiceias, ao problema do mal. O conceito impõe uma interpretação da queda que oferece uma alternativa a ideia de mal como criação divina. Os aspectos negativos da queda como o pecado original são colocados como uma etapa no plano divina de redenção. Filósofos como Alvin Plantinga defendem aspectos da teologia da felix culpa nos dias de hoje dentro de um quadro de considerações da chamada epistemologia reformada ligada à filosofia analítica.

4 Como se sabe, Schopenhauer consultou, no ano de 1814, na biblioteca de Weimar, os dois tomos do Oupnek'hat. Tratava-se de uma tradução latina de 1801-1802, realizada por Anquetil-Duperron, de 50 Upanișhads. A obra completa é composta por 108 Upanishads. A obra, a qual Schopenhauer teve acesso, era uma tradução de outra tradução. Essa coletânea foi traduzida do sânscrito para o persa em 1656-1657 sendo, assim, traduzida para o latim por Anquetil-Duperron em (1731-1805) e publicada em 1801/1802. 